\title{
Bacillus panaciterrae sp. nov., isolated from soil of a ginseng field
}

\author{
Leonid N. Ten, ${ }^{1,2} \dagger$ Sang-Hoon Baek, ${ }^{1} \dagger$ Wan-Taek Im, ${ }^{1}$ Qing-Mei Liu, ${ }^{1}$ \\ Zubair Aslam ${ }^{1}$ and Sung-Taik Lee ${ }^{1}$ \\ ${ }^{1}$ Department of Biological Sciences, Korea Advanced Institute of Science and Technology, \\ 373-1, Guseong-dong, Yuseong-gu, Daejeon 305-701, Republic of Korea \\ ${ }^{2}$ National University of Uzbekistan, Students Town, Tashkent, 700-174, Uzbekistan
}

Correspondence

Wan-Taek Im

wandra@kaist.ac.kr
The genus Bacillus was first described by Cohn in 1872 and comprises a vast diversity of physiological types (Claus \& Berkeley, 1986). The G $+\mathrm{C}$ contents (32-69 mol\%) of the known Bacillus species, as well as the results of DNA-DNA hybridization experiments, have revealed the heterogeneity of the genus. The introduction of molecular methods, especially the use of $16 \mathrm{~S}$ rRNA gene sequencing, has had a major impact on Bacillus taxonomy and has resulted in the splitting of the genus. In fact, in the last decade, 10 new genera have been separated from this original taxon (Wisotzkey et al., 1992; Ash et al., 1993; Shida et al., 1996; Heyndrickx et al., 1998; Wainø et al., 1999; Fortina et al., 2001; Nazina et al., 2001; Yoon et al., 2001). The genus currently includes more than 100 species (Euzéby, 2006). The members of this genus are considered to be ubiquitous because they have been isolated from a wide variety of aquatic and terrestrial environments, such as dust (Venkateswaran et al., 2003), river-mouth sediments (Ruiz-García et al., 2005), wastewater (Ajithkumar et al., 2002) and desert soils (Roberts et al., 1994).

†These authors contributed equally to this work.

The GenBank/EMBL/DDBJ accession number for the 16S rRNA gene sequence of strain Gsoil $1517^{\top}$ is AB245380.

A neighbour-joining tree including representatives of a wider selection of Bacillus species is available as supplementary material in IJSEM Online.
During the course of a study on the culturable aerobic/ facultatively anaerobic bacterial community in soil from a ginseng field in Pocheon Province, South Korea, a large number of novel bacterial strains were isolated. In this study, we have characterized one of these isolates, namely strain Gsoil $1517^{\mathrm{T}}$. Phenotypic, chemotaxonomic and phylogenetic analyses have established the affiliation of this isolate with the genus Bacillus. The data obtained also suggest that the isolate represents a novel species of the genus Bacillus.

Strain Gsoil $1517^{\mathrm{T}}$ was originally isolated from a soil sample from a ginseng field in Pocheon Province: the sample (1 g) was suspended in $10 \mathrm{ml} 50 \mathrm{mM}$ phosphate buffer ( $\mathrm{pH} 7 \cdot 0$ ) and the suspension was spread on one-fifth-strength modified R2A agar plates [containing $\left(1^{-1}\right) 0.25$ g tryptone, $0.25 \mathrm{~g}$ peptone, $0.25 \mathrm{~g}$ yeast extract, $0.125 \mathrm{~g}$ malt extract, $0.125 \mathrm{~g}$ beef extract, $0.25 \mathrm{~g}$ Casamino acids, $0.25 \mathrm{~g}$ soytone, $0.5 \mathrm{~g}$ glucose, $0.3 \mathrm{~g}$ soluble starch, $0.2 \mathrm{~g}$ xylan, $0.3 \mathrm{~g}$ sodium pyruvate, $0.3 \mathrm{~g} \mathrm{~K}_{2} \mathrm{HPO}_{4}, 0.05 \mathrm{~g} \mathrm{MgSO}_{4}, 0.05 \mathrm{~g}$ $\mathrm{CaCl}_{2}$ and $15 \mathrm{~g}$ agar] after being serially diluted in $50 \mathrm{mM}$ phosphate buffer $(\mathrm{pH} 7 \cdot 0)$. The plates were incubated at $30^{\circ} \mathrm{C}$ for 1 month. Single colonies on these plates were purified by transferring them onto new plates and subjecting them to an additional incubation on one-half-strength modified R2A for 3 days at $30^{\circ} \mathrm{C}$. The purified colonies were tentatively identified by partial sequencing of the $16 \mathrm{~S}$ rRNA gene ( $\mathrm{Im}$ et al., 2005). One isolate, Gsoil $1517^{\mathrm{T}}$, was routinely cultured on $\mathrm{R} 2 \mathrm{~A}$ agar at $30^{\circ} \mathrm{C}$ and maintained as a glycerol suspension $(20 \%, \mathrm{w} / \mathrm{v})$ at $-70^{\circ} \mathrm{C}$. 
The Gram reaction was performed by using the non-staining method, as described by Buck (1982). The cell morphology was observed under a Nikon light microscope at $\times 1000$, with cells grown for 3 days at $30^{\circ} \mathrm{C}$ on R2A agar. Catalase activity was determined by bubble production in $3 \%(\mathrm{v} / \mathrm{v})$ $\mathrm{H}_{2} \mathrm{O}_{2}$, and oxidase activity was determined using $1 \%(\mathrm{w} / \mathrm{v})$ tetramethyl-p-phenylenediamine. To study the assimilation of sole carbon sources, a defined liquid medium containing basal salt media (containing, $\mathrm{l}^{-1}, 1.8 \mathrm{~g} \mathrm{~K}_{2} \mathrm{HPO}_{4}, 1.08 \mathrm{~g}$ $\mathrm{KH}_{2} \mathrm{PO}_{4}, 0.5 \mathrm{~g} \mathrm{NaNO}, 0.5 \mathrm{~g} \mathrm{NH}_{4} \mathrm{Cl}, 0.1 \mathrm{~g} \mathrm{KCl}, 0.1 \mathrm{~g}$ $\mathrm{MgSO}_{4}$ and $0.05 \mathrm{~g} \mathrm{CaCl}_{2}$ ) was used. A vitamin solution (Widdel \& Bak, 1992), a trace elements solution (SL-10; Widdel et al., 1983) and a selenite/tungstate solution (Tschech \& Pfennig, 1984) were added to this medium, and the $\mathrm{pH}$ was then adjusted to $6 \cdot 8$. This liquid medium was poured into 96 wells and $25 \times$ stock solutions of carbon sources (filter-sterilized) were then added individually to each well. Growth was examined visually after incubation at $30{ }^{\circ} \mathrm{C}$ for 7 days. The negative-control well did not contain a carbon source. The positive-control culture was grown in a well containing R2A. Fermentative and oxidative carbohydrate metabolism were tested for by examining growth in $\mathrm{O} /$ F basal medium containing bromothymol blue (Atlas, 1993) and supplemented with $1 \%$ carbohydrate [soft-agar stabs with (fermentative) and without (oxidative) a sterile mineral oil overlay]. The tubes containing $\mathrm{O} / \mathrm{F}$ medium were incubated at $30^{\circ} \mathrm{C}$ for 5 days. Some physiological characteristics were determined with API 20E galleries, according to the instructions of the manufacturer (bioMerieux). Anaerobic growth was examined in serum bottles by adding thioglycolate $\left(1 \mathrm{~g} \mathrm{l}^{-1}\right)$ to $\mathrm{R} 2 \mathrm{~A}$ broth, in each case, to three serum bottles $(25 \mathrm{ml})$ containing $23 \mathrm{ml}$ R2A broth; the rubber caps were sealed with aluminium lids and then the upper air layer was replaced with nitrogen gas. An anaerobic nitrate reduction test (to determine the final electron acceptor) was performed in serum bottles by adding thioglycolate $\left(1 \mathrm{~g} \mathrm{l}^{-1}\right)$ to $\mathrm{R} 2 \mathrm{~A}$ broth and substituting the air in the headspace with nitrogen gas while nitrate was added as $\mathrm{KNO}_{3}$ at concentrations of $10 \mathrm{mM}$. Aerobic nitrate reduction was later confirmed by inoculating, in each case, three serum bottles $(25 \mathrm{ml})$ containing $12 \mathrm{ml} \mathrm{R} 2 \mathrm{~A}$ broth, while nitrate was added as $\mathrm{KNO}_{3}$ at a concentration of $10 \mathrm{mM}$. The reduction of nitrate was monitored by using an ion chromatograph (model 790 personal IC; Metrohm) equipped with a conductivity detector and an anionexchange column (Metrosep Anion Supp 4; Metrohm). Tests for the degradation of DNA [DNASE agar (Scharlau), with DNase activity detected by flooding plates with $1 \mathrm{M}$ HCl], casein, chitin, starch (Atlas, 1993), lipid (Kouker \& Jaeger, 1987), xylan and cellulose (Ten et al., 2004) were performed and evaluated after 7 days. Growth at different temperatures $\left(4,15,25,30,37,42\right.$ and $\left.45^{\circ} \mathrm{C}\right)$ and various $\mathrm{pH}$ values ( $\mathrm{pH} 4 \cdot 0-10 \cdot 0$, using increments of $0.5 \mathrm{pH}$ units) was assessed after 5 days incubation. Salt tolerance was tested on R2A agar supplemented with 1-10\% (w/v) $\mathrm{NaCl}$ after 5 days incubation. Growth at $30^{\circ} \mathrm{C}$ on nutrient agar, trypticase soy agar (TSA; Difco) and MacConkey agar was also evaluated.
An almost-complete 16S rRNA gene sequence for strain Gsoil $1517^{\mathrm{T}}$ was determined as described below. Extraction of the genomic DNA was achieved using a commercial genomic DNA-extraction kit (Core Biosystem), and PCRmediated amplification of the 16S rRNA gene and sequencing of the purified PCR product were carried out according to Kim et al. (2005). The full sequence of the $16 \mathrm{~S}$ rRNA gene was compiled using SeqMan software (DNASTAR). The 16S rRNA gene sequences of related taxa were obtained from the GenBank database. Multiple alignments were performed by using the CLUSTAL_X program (Thompson et al., 1997). Gaps were edited in the BioEdit program (Hall, 1999). The evolutionary distances were calculated using the Kimura two-parameter model (Kimura, 1983). The phylogenetic tree was constructed using the neighbour-joining method (Saitou \& Nei, 1987) and maximum parsimony (Fitch, 1971) in the MEGA3 program (Kumar et al., 2004), with bootstrap values based on 1000 replications (Felsenstein, 1985).

To measure the $\mathrm{G}+\mathrm{C}$ content of the chromosomal DNA, the genomic DNA was extracted and purified as described by Moore (1995), enzymically degraded into nucleosides. The DNA $\mathrm{G}+\mathrm{C}$ content was then determined as described by Mesbah et al. (1989), using reversed-phase HPLC. Isoprenoid quinones were extracted with chloroform/ methanol $(2: 1, \mathrm{v} / \mathrm{v})$, evaporated under vacuum conditions and re-extracted in $\mathrm{n}$-hexane/water $(1: 1, \mathrm{v} / \mathrm{v})$. The crude quinone in n-hexane was purified using silica Sep-Pak Vac cartridges (Waters) and subsequently analysed by HPLC, as described previously (Hiraishi et al., 1996). Cellular fatty acids were analysed in organisms grown on TSA for 2 days. The cellular fatty acids were saponified, methylated and extracted according to the protocol of the Sherlock Microbial Identification System (MIDI). The fatty acids were then analysed by gas chromatography (model 6890; Hewlett Packard) using the Microbial Identification software package (Sasser, 1990).

Strain Gsoil $1517^{\mathrm{T}}$ was Gram-positive, spore-forming, nonmotile and rod-shaped. Central ellipsoidal endospores were observed in swollen sporangia. Colonies grown on R2A agar plates (Difco) for 2 days were smooth, shiny, circular, entire, light-yellowish white in colour and $1 \cdot 5-2 \cdot 0 \mathrm{~mm}$ in diameter. The oxidase and catalase reactions were positive. On R2A agar, the optimum temperature for growth was $30{ }^{\circ} \mathrm{C}$ and the optimum $\mathrm{pH}$ range was $6 \cdot 5-7 \cdot 0$. Other physiological characteristics of strain Gsoil $1517^{\mathrm{T}}$ are summarized in the species description. The phenotypic and chemotaxonomic characteristics that differentiate strain Gsoil $1517^{\mathrm{T}}$ from related Bacillus species are listed in Table 1.

The 16S rRNA gene sequence of strain Gsoil $1517^{\mathrm{T}}$ was a continuous stretch of $1476 \mathrm{bp}$. Comparative 16S rRNA gene sequence analyses showed that the strain was phylogenetically affiliated with Bacillus species. The phylogenetic tree based on the neighbour-joining method placed strain Gsoil $1517^{\mathrm{T}}$ within the radiation of the cluster comprising Bacillus 
Table 1. Phenotypic characteristics of strain Gsoil $1517^{\top}$ and some related Bacillus species

Taxa: 1, Gsoil $1517^{\mathrm{T}}$ (data from this study); 2, B. funiculus (Ajithkumar et al., 2001, 2002); 3, Bacillus cereus (Claus \& Berkeley, 1986; Priest et al., 1988); 4, Bacillus pseudomycoides (Nakamura, 1998); 5, Bacillus mycoides (Ajithkumar et al., 2001, 2002; Venkateswaran et al., 2003). Results are scored as: +, positive; V, variable among strains; -, negative; ND, no data available. All species produce centrally located ellipsoidal or oval spores.

\begin{tabular}{|c|c|c|c|c|c|}
\hline Characteristic & 1 & 2 & 3 & 4 & 5 \\
\hline Gram staining & + & - & + & + & + \\
\hline Budding cells & - & + & - & - & - \\
\hline Anaerobic growth & + & - & + & + & + \\
\hline \multicolumn{6}{|l|}{ Growth at/in: } \\
\hline $1 \%(\mathrm{w} / \mathrm{v}) \mathrm{NaCl}$ & + & ND & + & + & + \\
\hline $5 \%(\mathrm{w} / \mathrm{v}) \mathrm{NaCl}$ & - & - & + & + & - \\
\hline $10^{\circ} \mathrm{C}$ & - & - & $\mathrm{V}$ & - & ND \\
\hline $42{ }^{\circ} \mathrm{C}$ & + & - & $\mathrm{V}$ & - & ND \\
\hline Oxidase & + & - & $\mathrm{V}$ & - & $\mathrm{ND}$ \\
\hline Catalase & + & + & ND & + & ND \\
\hline Citrate utilization & + & - & + & $\mathrm{V}$ & - \\
\hline Indole production & - & - & $\mathrm{ND}$ & - & - \\
\hline Voges-Proskauer test & - & + & + & + & + \\
\hline \multicolumn{6}{|l|}{ Hydrolysis of: } \\
\hline Casein & - & - & + & + & + \\
\hline Gelatin & + & - & + & $\mathrm{ND}$ & + \\
\hline Starch & - & + & $\mathrm{V}$ & + & $\mathrm{ND}$ \\
\hline \multicolumn{6}{|l|}{ Acid production from: } \\
\hline D-Glucose & - & ND & + & + & + \\
\hline D-Mannitol & - & ND & - & - & + \\
\hline $\begin{array}{l}\text { DNA G+C content } \\
(\mathrm{mol} \%)\end{array}$ & $47 \cdot 8$ & $37 \cdot 2$ & $31 \cdot 7-40 \cdot 1$ & $34-36$ & $35 \cdot 5-36 \cdot 2$ \\
\hline
\end{tabular}

species; the strain joined Bacillus funiculus JCM $11201^{\mathrm{T}}$ with a bootstrap resampling value of $96.0 \%$ (Fig. 1). Strain Gsoil $1517^{\mathrm{T}}$ exhibited $16 \mathrm{~S}$ rRNA gene sequence similarity of $96 \cdot 8 \%$ with respect to the type strain of $B$. funiculus and showed sequence similarities below $94 \cdot 3 \%$ with respect to the type strains of other Bacillus species with validly published names (see an extended tree, available as Supplementary Fig. S1 in IJSEM Online).

DNA-DNA hybridization between strain Gsoil $1517^{\mathrm{T}}$ and the nearest phylogenetic neighbours was not attempted since strains differing by $>3.0 \%$ at the $16 \mathrm{~S}$ rRNA gene sequence level are unlikely to exhibit $>70 \%$ relatedness at the whole-genome level (Stackebrandt \& Goebel, 1994).

The $\mathrm{G}+\mathrm{C}$ content of the genomic DNA was $47 \cdot 8 \mathrm{~mol} \%$ and the predominant respiratory quinone was MK-7. The fatty acid profile of strain Gsoil $1517^{\mathrm{T}}$ is shown in Table 2 and was compared with those available for phylogenetically related Bacillus strains. Strain Gsoil $1517^{\mathrm{T}}$ contained large amounts of iso- and anteiso-branched fatty acids; the major components were 13-methyltetradecanoic acid (iso- $\mathrm{C}_{15: 0}$ ), 12-methyltetradecanoic acid (anteiso- $\mathrm{C}_{15: 0}$ ) and 12-methyltridecanoic acid (iso- $\mathrm{C}_{14: 0}$ ), which is typical of members of the genus Bacillus (Kämpfer, 1994). Some qualitative and quantitative differences in fatty acid content could be observed between strain Gsoil $1517^{\mathrm{T}}$ and the phylogenetically closest relatives (Table 1), perhaps because of differences in cultivation conditions (Kämpfer, 1994; Ajithkumar et al., 2002; Venkateswaran et al., 2003).

All of the characteristics determined for strain Gsoil $1517^{\mathrm{T}}$ were in accordance with those of the genus Bacillus. However, on the basis of phylogenetic distances from Bacillus species with validly published names, indicated by the relatively low 16S rRNA gene sequence similarities $(<97 \%)$ and the combination of unique phenotypic characteristics (Table 1), it is demonstrable that Gsoil $1517^{\mathrm{T}}$ is not affiliated with any known species of the genus Bacillus. Therefore, on the basis of the data presented above, strain Gsoil $1517^{\mathrm{T}}$ represents a novel species within the genus Bacillus, for which the name Bacillus panaciterrae sp. nov. is proposed.

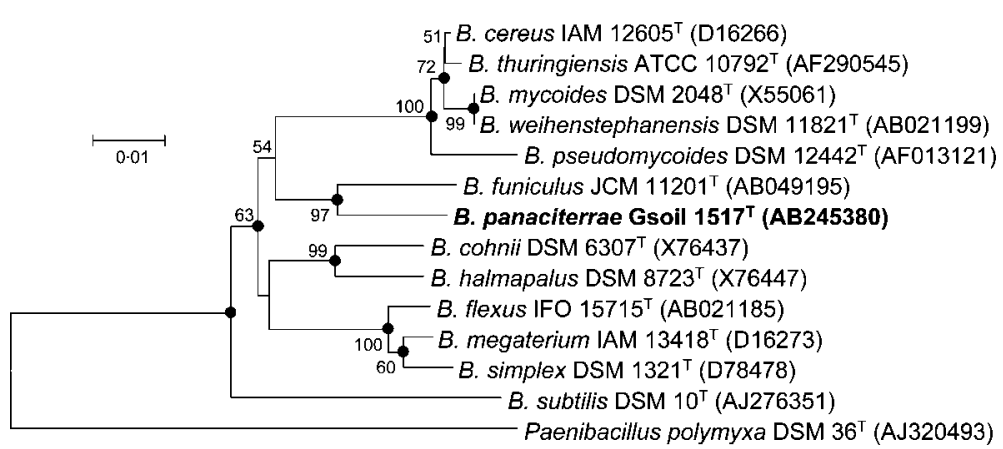

Fig. 1. Neighbour-joining tree, based on 16S rRNA gene sequences, showing the phylogenetic positions of Gsoil $1517^{\top}$ and selected Bacillus species. Bootstrap values (expressed as percentages of 1000 replications) greater than $50 \%$ are shown at branch points. Filled circles indicate that the corresponding nodes were also recovered in the tree generated with the maximum-parsimony algorithm. The tree was rooted using Paenibacillus polymyxa DSM $36^{\top}$ as an outgroup. Bar, 0.01 substitutions per nucleotide position. An extended tree including representatives of a wider selection of Bacillus species is available as Supplementary Fig. S1 in IJSEM Online. 
Table 2. Cellular fatty acid profiles of strain Gsoil $1517^{\top}$ and related Bacillus species

Strains: 1, Gsoil $1517^{\mathrm{T}}$ (data determined after growth on trypticase soy agar for 2 days in this study); 2, B. funiculus JCM $11201^{\mathrm{T}}$ (nutrient broth/glucose agar for 4 days at $30^{\circ} \mathrm{C}$; data from Ajithkumar et al., 2002); 3, B. cereus DSM $31^{\mathrm{T}}$ (tryptone soy agar for $24 \mathrm{~h}$ at $30^{\circ} \mathrm{C}$; Kämpfer, 1994); 4, B. mycoides ATCC $6462^{\mathrm{T}}$ (trypticase soy broth, overnight at $32{ }^{\circ} \mathrm{C}$; Venkateswaran et al., 2003). Fatty acid data have not been reported for B. pseudomycoides. -, Not detected/reported.

\begin{tabular}{|c|c|c|c|c|}
\hline Fatty acid & 1 & 2 & 3 & 4 \\
\hline \multicolumn{5}{|l|}{ Straight-chain saturated } \\
\hline $\mathrm{C}_{14: 0}$ & - & - & $3 \cdot 5$ & $3 \cdot 0$ \\
\hline $\mathrm{C}_{16: 0}$ & $6 \cdot 0$ & $8 \cdot 8$ & $3 \cdot 6$ & $6 \cdot 2$ \\
\hline $\mathrm{C}_{17: 0}$ & - & $1 \cdot 2$ & - & - \\
\hline $\mathrm{C}_{18: 0}$ & $1 \cdot 1$ & $1 \cdot 9$ & - & - \\
\hline \multicolumn{5}{|l|}{ Branched saturated } \\
\hline iso- $\mathrm{C}_{12: 0}$ & - & - & - & $1 \cdot 4$ \\
\hline iso- $\mathrm{C}_{13: 0}$ & $3 \cdot 6$ & - & $9 \cdot 5$ & $7 \cdot 6$ \\
\hline iso- $\mathrm{C}_{14: 0}$ & $9 \cdot 7$ & - & $4 \cdot 0$ & $5 \cdot 0$ \\
\hline iso- $\mathrm{C}_{15: 0}$ & $42 \cdot 4$ & $18 \cdot 0$ & $35 \cdot 9$ & $20 \cdot 9$ \\
\hline iso- $\mathrm{C}_{16: 0}$ & $2 \cdot 5$ & $3 \cdot 8$ & $1 \cdot 3$ & $10 \cdot 2$ \\
\hline iso- $\mathrm{C}_{17: 0}$ & $1 \cdot 9$ & - & $8 \cdot 9$ & $6 \cdot 9$ \\
\hline anteiso- $\mathrm{C}_{13: 0}$ & - & - & $0 \cdot 6$ & $1 \cdot 9$ \\
\hline anteiso- $\mathrm{C}_{15: 0}$ & $17 \cdot 4$ & $44 \cdot 3$ & $4 \cdot 7$ & $4 \cdot 5$ \\
\hline anteiso- $\mathrm{C}_{17: 0}$ & $1 \cdot 1$ & - & $0 \cdot 8$ & $2 \cdot 2$ \\
\hline \multicolumn{5}{|l|}{ Unsaturated } \\
\hline $\mathrm{C}_{11: 1}$ & - & $4 \cdot 3$ & - & - \\
\hline Summed feature $2^{\star}$ & $2 \cdot 4$ & - & - & - \\
\hline $\mathrm{C}_{16: 1} \omega 11 c$ & $1 \cdot 6$ & - & $1 \cdot 8$ & $4 \cdot 0$ \\
\hline $\mathrm{C}_{16: 1}$ (branched) & - & - & $3 \cdot 3$ & - \\
\hline $\mathrm{C}_{16: 1} \omega 7 c$ alcohol & $1 \cdot 8$ & - & - & $4 \cdot 6$ \\
\hline Summed feature $4^{\star}$ & $1 \cdot 4$ & - & - & $7 \cdot 1$ \\
\hline anteiso- $\mathrm{C}_{16: 1}$ & - & - & $8 \cdot 4$ & - \\
\hline iso- $\mathrm{C}_{17: 1} \omega 10 c$ & $0 \cdot 8$ & - & $0 \cdot 8$ & $11 \cdot 8$ \\
\hline Summed feature $5^{*}$ & - & - & - & $2 \cdot 7$ \\
\hline anteiso- $\mathrm{C}_{16: 1}$ & - & - & $8 \cdot 4$ & - \\
\hline anteiso- $\mathrm{C}_{17: 1}$ & - & - & $3 \cdot 4$ & - \\
\hline $\mathrm{C}_{17: 1}$ (branched) & - & - & $6 \cdot 3$ & - \\
\hline $\mathrm{C}_{20: 2} \omega 16,9 c$ & $0 \cdot 9$ & - & - & - \\
\hline \multicolumn{5}{|l|}{ Unknown $\dagger$} \\
\hline ECL $13 \cdot 961$ & $5 \cdot 4$ & - & - & - \\
\hline $\mathrm{C}_{15: 4}$ hydroxylated, branched & - & $13 \cdot 8$ & - & - \\
\hline
\end{tabular}

*Summed features represent groups of two or three fatty acids that could not be separated by GLC with the MIDI system. Summed feature 2 contained $\mathrm{C}_{13: 0} 3-\mathrm{OH}$ and/or iso- $\mathrm{C}_{15: 1} \mathrm{H}$. Summed feature 4 contained iso- $\mathrm{C}_{15: 0} 2-\mathrm{OH}$ and/or $\mathrm{C}_{16: 1} \omega 7 c$. Summed feature 5 contained iso- $\mathrm{C}_{17: 1} \mathrm{I}$ and/or anteiso- $\mathrm{C}_{17: 1} \mathrm{~B}$.

†Unknown fatty acids have no names listed in the peak library file of the MIDI system and therefore cannot be identified. ECL, Equivalent chain length.

\section{Description of Bacillus panaciterrae sp. nov.}

Bacillus panaciterrae (pa.na.ci.ter'rae. N.L. n. Panax -acis scientific name for ginseng; L. n. terra soil; N.L. gen. n. panaciterrae of soil of a ginseng field).

Cells are Gram-positive, rod-shaped, $0.5-0.8 \mu \mathrm{m}$ in diameter and $3 \cdot 0-5 \cdot 0 \mu \mathrm{m}$ in length, non-motile and occur singly or in chains. Central ellipsoidal endospores are observed in swollen sporangia. The optimum temperature for growth is $30^{\circ} \mathrm{C}$ and the growth temperature range is between 20 and $45^{\circ} \mathrm{C}$. The minimum $\mathrm{pH}$ for growth lies between $5 \cdot 0$ and $5 \cdot 5$, the optimum $\mathrm{pH}$ is $6 \cdot 5-7 \cdot 0$ and the maximum $\mathrm{pH}$ lies between $8 \cdot 0$ and $8 \cdot 5$. Tolerates $1 \%(\mathrm{w} / \mathrm{v})$ $\mathrm{NaCl}$, but not $2 \%$. Growth occurs on TSA but not on MacConkey agar. Able to hydrolyse chitin, but not starch, cellulose, DNA, olive oil or xylan. The following substrates are utilized for growth: D-glucose, D-fructose, L-xylose, $\mathrm{N}$ acetylglucosamine, pyruvate, acetate, 3-hydroxybutyrate, valerate, fumarate, salicin, citrate, lactate, malate, succinate, tartrate, sucrose, D-trehalose, gluconate, inositol (weakly), D-mannitol, xylitol, glycerol, inulin, L-alanine, L-arginine, Lasparagine, L-aspartate, L-glutamate, L-glutamine, L-histidine and L-proline. The following substrates are not utilized for growth: D-galactose, D-mannose, D-fucose, ethanol, L-rhamnose, L-sorbose, D- and L-arabinose, Dlyxose, D-ribose, D-xylose, formate, propionate, caprate, maleate, phenylacetate, benzoate, 3-hydroxybenzoate, 4hydroxybenzoate, malonate, glutarate, itaconate, adipate, suberate, oxalate, D-cellobiose, D-lactose, D-maltose, Dmelibiose, D-raffinose, D-adonitol, dulcitol, D-sorbitol, amygdalin, methanol, glycogen, dextran, L-cysteine, glycine, L-isoleucine, L-leucine, L-lysine, L-threonine, Lmethionine, L-phenylalanine, L-serine, L-tryptophan, Ltyrosine and L-valine. In API $20 \mathrm{E}$ tests, positive for gelatin hydrolysis and negative for $\beta$-galactosidase, arginine dihydrolase, lysine decarboxylase, ornithine decarboxylase, tryptophan deaminase, indole and $\mathrm{H}_{2} \mathrm{~S}$ production, the Voges-Proskauer reaction and urease production. Acid is not produced from the following carbohydrates: Larabinose, D-mannitol, inositol, D-sorbitol, L-rhamnose, sucrose, D-melibiose, D-glucose and amygdalin. The major fatty acids are iso- $\mathrm{C}_{15: 0}(42 \cdot 4 \%)$, anteiso- $\mathrm{C}_{15: 0}$ $(17 \cdot 4)$ and iso- $\mathrm{C}_{14: 0}(9 \cdot 7 \%)$. The $\mathrm{G}+\mathrm{C}$ content of genomic DNA is $47 \cdot 8 \mathrm{~mol} \%$. MK-7 is the predominant respiratory quinone.

The type strain, Gsoil $1517^{\mathrm{T}}\left(=\mathrm{KCTC} 13929^{\mathrm{T}}=\mathrm{CCUG}\right.$ $52470^{\mathrm{T}}=$ LMG $23408^{\mathrm{T}}$ ), was isolated from soil from a ginseng field in Pocheon Province, South Korea.

\section{Acknowledgements}

This work was supported by the Brain Pool Program (grant 031-4-17) funded by the Ministry of Science and Technology and by the $21 \mathrm{C}$ Frontier Microbial Genomics and Application Center Program, Ministry of Science and Technology (grant MG05-0101-4-0), Republic of Korea. 


\section{References}

Ajithkumar, V. P., Ajithkumar, B., Mori, K., Takamizawa, K., Iriye, R. \& Tabata, S. (2001). A novel filamentous Bacillus sp., strain NAF001, forming endospores and budding cells. Microbiology 147, 1415-1423.

Ajithkumar, V. P., Ajithkumar, B., Iriye, R. \& Sakai, T. (2002). Bacillus funiculus sp. nov., novel filamentous isolates from activated sludge. Int J Syst Evol Microbiol 52, 1141-1144.

Ash, C., Priest, F. G. \& Collins, M. D. (1993). Molecular identification of rRNA group 3 bacilli (Ash, Farrow, Wallbanks and Collins) using a PCR probe test. Proposal for the creation of a new genus Paenibacillus. Antonie van Leeuwenhoek 64, 253-260.

Atlas, R. M. (1993). Handbook of Microbiological Media. Edited by L. C. Parks. Boca Raton, FL: CRC Press.

Buck, J. D. (1982). Nonstaining (KOH) method for determination of Gram reactions of marine bacteria. Appl Environ Microbiol 44, 992-993.

Claus, D. \& Berkeley, R. C. W. (1986). Genus Bacillus Cohn 1872. In Bergey's Manual of Systematic Bacteriology, vol. 2, pp. 1105-1139. Edited by P. H. A. Sneath, N. S. Mair, M. E. Sharpe \& J. G. Holt. Baltimore: Williams \& Wilkins.

Euzéby, J. P. (2006). List of Prokaryotic Names with Standing in Nomenclature. http://www.bacterio.cict.fr/index.html

Felsenstein, J. (1985). Confidence limits on phylogenies: an approach using the bootstrap. Evolution 39, 783-791.

Fitch, W. M. (1971). Toward defining the course of evolution: minimum change for a specific tree topology. Syst Zool 20, 406-416.

Fortina, M. G., Pukall, R., Schumann, P., Mora, D., Parini, C., Manachini, P. L. \& Stackebrandt, E. (2001). Ureibacillus gen. nov., a new genus to accommodate Bacillus thermosphaericus (Andersson et al. 1995), emendation of Ureibacillus thermosphaericus and description of Ureibacillus terrenus sp. nov. Int J Syst Evol Microbiol 51, 447-455.

Hall, T. A. (1999). BioEdit: a user-friendly biological sequence alignment editor and analysis program for Windows 95/98/NT. Nucleic Acids Symp Ser 41, 95-98.

Heyndrickx, M., Lebbe, L., Kersters, K., De Vos, P., Forsyth, G. \& Logan, N. A. (1998). Virgibacillus: a new genus to accommodate Bacillus pantothenticus (Proom and Knight 1950). Emended description of Virgibacillus pantothenticus. Int J Syst Bacteriol 48, 99-106.

Hiraishi, A., Ueda, Y., Ishihara, J. \& Mori, T. (1996). Comparative lipoquinone analysis of influent sewage and activated sludge by highperformance liquid chromatography and photodiode array detection. J Gen Appl Microbiol 42, 457-469.

Im, W.-T., Jung, H.-M., Cui, Y.-S., Liu, Q.-M., Zhang, S.-L. \& Lee, S.-T. (2005). Cultivation of the three hundreds of bacterial species from the soil of the ginseng field and mining the novel lineage bacteria. In Proceedings of the International Meeting of the Federation of Korean Microbiological Societies, abstract A035, p. 169. Seoul: Federation of Korean Microbiological Societies.

Kämpfer, P. (1994). Limits and possibilities of total fatty acid analysis for classification and identification of Bacillus species. Syst Appl Microbiol 17, 86-98.

Kim, M. K., Im, W.-T., Ohta, H., Lee, M. \& Lee, S.-T. (2005). Sphingopyxis granuli sp. nov., a $\beta$-glucosidase-producing bacterium in the family Sphingomonadaceae in the $\alpha-4$ subgroup of the Proteobacteria. J Microbiol 43, 152-157.

Kimura, M. (1983). The Neutral Theory of Molecular Evolution. Cambridge: Cambridge University Press.

Kouker, G. \& Jaeger, K.-E. (1987). Specific and sensitive plate assay for bacterial lipases. Appl Environ Microbiol 53, 211-213.

Kumar, S., Tamura, K. \& Nei, M. (2004). MEGA3: integrated software for molecular evolutionary genetics analysis and sequence alignment. Brief Bioinform 5, 150-163.
Mesbah, M., Premachandran, U. \& Whitman, W. B. (1989). Precise measurement of the $\mathrm{G}+\mathrm{C}$ content of deoxyribonucleic acid by highperformance liquid chromatography. Int J Syst Bacteriol 39, 159-167.

Moore, D. D. (1995). Preparation and analysis of DNA. In Current Protocols in Molecular Biology, pp. 2.4.1-2.4.2. Edited by F. W. Ausubel, R. Brent, R. E. Kingston, D. D. Moore, J. G. Seidman, J. A. Smith \& K. Struhl. New York: Wiley.

Nakamura, L. K. (1998). Bacillus pseudomycoides sp. nov. Int J Syst Bacteriol 48, 1031-1035.

Nazina, T. N., Tourova, T. P., Poltaraus, A. B. \& 8 other authors (2001). Taxonomic study of aerobic thermophilic bacilli: descriptions of Geobacillus subterraneus gen. nov., sp. nov. and Geobacillus uzenensis sp. nov. from petroleum reservoirs and transfer of Bacillus stearothermophilus, Bacillus thermocatenulatus, Bacillus thermoleovorans, Bacillus kaustophilus, Bacillus thermoglucosidasius and Bacillus thermodenitrificans to Geobacillus as the new combinations $G$. stearothermophilus, G. thermocatenulatus, G. thermoleovorans, G. kaustophilus, G. thermoglucosidasius and G. thermodenitrificans. Int J Syst Evol Microbiol 51, 433-446.

Priest, F. G., Goodfellow, M. \& Todd, C. (1988). A numerical classification of the genus Bacillus. J Gen Microbiol 134, 1847-1882.

Roberts, M. S., Nakamura, L. K. \& Cohan, F. M. (1994). Bacillus mojavensis sp. nov., distinguishable from Bacillus subtilis by sexual isolation, divergence in DNA sequence, and differences in fatty acid composition. Int J Syst Bacteriol 44, 256-264.

Ruiz-García, C., Quesada, E., Martínez-Checa, F., Llamas, I., Urdaci, M. C. \& Béjar, V. (2005). Bacillus axarquiensis sp. nov. and Bacillus malacitensis sp. nov., isolated from river-mouth sediments in southern Spain. Int J Syst Evol Microbiol 55, 1279-1285.

Saitou, N. \& Nei, M. (1987). The neighbor-joining method: a new method for reconstructing phylogenetic trees. Mol Biol Evol 4, 406-425.

Sasser, M. (1990). Identification of bacteria by gas chromatography of cellular fatty acids. MIDI Technical Note 101. Newark, DE: MIDI.

Shida, O., Takagi, H., Kadowaki, K. \& Komagata, K. (1996). Proposal for two new genera, Brevibacillus gen. nov. and Aneurinibacillus gen. nov. Int J Syst Bacteriol 46, 939-946.

Stackebrandt, E. \& Goebel, B. M. (1994). Taxonomic note: a place for DNA-DNA reassociation and $16 \mathrm{~S}$ rRNA sequence analysis in the present species definition in bacteriology. Int J Syst Bacteriol 44, 846-849.

Ten, L. N., Im, W.-T., Kim, M.-K., Kang, M.-S. \& Lee, S.-T. (2004). Development of a plate technique for screening of polysaccharidedegrading microorganisms by using a mixture of insoluble chromogenic substrates. J Microbiol Methods 56, 375-382.

Thompson, J. D., Gibson, T. J., Plewniak, F., Jeanmougin, F. \& Higgins, D. G. (1997). The CLUSTAL_X windows interface: flexible strategies for multiple sequence alignment aided by quality analysis tools. Nucleic Acids Res 25, 4876-4882.

Tschech, A. \& Pfennig, N. (1984). Growth yield increase linked to caffeate reduction in Acetobacterium woodii. Arch Microbiol 137, 163-167.

Venkateswaran, K., Kempf, M., Chen, F., Satomi, M., Nicholson, W. \& Kern, R. (2003). Bacillus nealsonii sp. nov., isolated from a spacecraft-assembly facility, whose spores are $\gamma$-radiation resistant. Int J Syst Evol Microbiol 53, 165-172.

Wainø, M., Tindall, B. J., Schumann, P. \& Ingvorsen, K. (1999). Gracilibacillus gen. nov., with description of Gracilibacillus halotolerans gen. nov., sp. nov.; transfer of Bacillus dipsosauri to Gracilibacillus dipsosauri comb. nov., and Bacillus salexigens to the genus Salibacillus gen. nov. as Salibacillus salexigens comb. nov. Int J Syst Bacteriol 49, 821-831.

Widdel, F. \& Bak, F. (1992). Gram-negative mesophilic sulphatereducing bacteria. In The Prokaryotes, 2nd edn, pp. 3352-3378. 
Edited by A. Balows, H. G. Trüper, M. Dworkin, W. Harder \& K. H. Schleifer. New York: Springer.

Widdel, F., Kohring, G. \& Mayer, F. (1983). Studies in dissimilatory sulfate-reducing bacteria that decompose fatty acids. III. Characterization of the filamentous gliding Desulfonema limicola gen. nov., sp. nov. and Desulfonema magnum sp. nov. Arch Microbiol 134, 286-294.

Wisotzkey, J. D., Jurtshuk, P., Jr, Fox, G. E., Deinhard, G. \& Poralla, K. (1992). Comparative sequence analyses on the $16 \mathrm{~S}$ rRNA (rDNA) of Bacillus acidocaldarius, Bacillus acidoterrestris, and Bacillus cycloheptanicus and proposal for creation of a new genus, Alicyclobacillus gen. nov. Int J Syst Bacteriol 42, 263-269.

Yoon, J.-H., Weiss, N., Lee, K.-C., Lee, I.-S., Kang, K. H. \& Park, Y.-H. (2001). Jeotgalibacillus alimentarius gen. nov., sp. nov., a novel bacterium isolated from jeotgal with L-lysine in the cell wall, and reclassification of Bacillus marinus Rüger 1983 as Marinibacillus marinus gen. nov., comb. nov. Int J Syst Evol Microbiol 51, 2087-2093. 